Antarctic fur seals at Tristan da Cunha islands

\title{
Vagrant Antarctic fur seals at the Tristan da Cunha Islands
}

\author{
M.N. Bester* ${ }^{1}$, P.G. Ryan ${ }^{2}$, W.A. Bester ${ }^{1}$, T. Glass ${ }^{3}$ \\ ${ }^{1}$ Mammal Research Institute, Department of Zoology and Entomology, University of Pretoria, Private Bag \\ X20, Hatfield, Pretoria 0028, South Africa \\ ${ }^{2}$ Percy FitzPatrick Institute, DST/NRF Centre of Excellence, University of Cape Town, Rondebosch 7701, \\ South Africa \\ ${ }^{3}$ Tristan da Cunha Conservation Department, Edinburgh, Tristan da Cunha, South Atlantic \\ *To whom correspondence should be addressed. Email: mnbester@zoology.up.ac.za
}

\begin{abstract}
Antarctic fur seals Arctocephalus gazella mainly breed at islands south of the Antarctic Polar Front, but stragglers occasionally occur farther north, with records from Gough Island $\left(40^{\circ} \mathrm{S}, 10^{\circ} \mathrm{W}\right)$ in the central South Atlantic Ocean in October/November 2005 and September/October 2009 . We report the first record from Tristan da Cunha $\left(37^{\circ} \mathrm{S}, 12^{\circ} \mathrm{W}\right)$ in September 2013, and another individual that was observed at Gough Island. Both individuals were lean, lethargic subadult males that were present before the onset of the breeding (pupping) season of the resident populations of Subantarctic fur seals $A$. tropicalis.
\end{abstract}

Keywords: Antarctic fur seals, Tristan da Cunha Islands, Subantarctic fur seals, Southern Ocean

Antarctic fur seals Arctocephalus gazella mainly breed at localities south of the Antarctic Polar Front, but have successfully colonised some sub-Antarctic islands north of this Front (Condy 1978; Bester 1984), where they are largely replaced by the Subantarctic fur seal A. tropicalis. Vagrant Antarctic fur seals occasionally occur farther north (Acevedo et al. 2011), reaching Gough Island $\left(40^{\circ} \mathrm{S}, 10^{\circ} \mathrm{W}\right)$ in the central South Atlantic Ocean (Wilson et al. 2005; Bester and Reisinger 2010), and we report a further range extension in this region. 
Antarctic fur seals at Tristan da Cunha islands

From 13 to 19 September 2013 the only breeding colony of A. tropicalis at The Caves (37 09'S, $\left.12^{\circ} 10^{\prime} \mathrm{W}\right)$, Tristan da Cunha Island (Bester and Ryan 2007), in the southern Atlantic Ocean (Fig. 1) was searched daily for lactating females for satellite transmitter deployment. One A. gazella was located on a partly vegetated beach of rounded stones within $\sim 300 \mathrm{~m}$ of the small ( $\sim 30$ pups) A. tropicalis breeding colony on 16 September, but could not be located the next day. The two species were separated on vocal (St. Clair Hill et al. 2001) and external morphological (Condy 1978) characteristics. The lethargic, lean, subadult male was largely unresponsive to very close approaches (one metre) to ascertain its sex, and to estimate its body length (nose to tail) by placing a rope of known length parallel to the long axis of its body. The $1.2 \mathrm{~m}$ animal was not obviously injured, but appeared fatigued and in poor condition with ribs showing (Fig. 2a). Alerted to the presence of the vagrant at Tristan da Cunha (TdC), a search was initiated on the beaches close to the Meteorological Station on Gough Island $\left(40^{\circ} 20^{\prime} \mathrm{S}\right.$, $09^{\circ} 54^{\prime} \mathrm{W}$ ) to the southeast of $\mathrm{TdC}$ (Fig. 1), and located another lean, lethargic, $\sim 1.2 \mathrm{~m}$ long subadult male A. gazella hauled out on 21 September 2013 (Fig. 2b). Despite the 5day lapse between the sightings at TdC and $380 \mathrm{~km}$ distant Gough Island (GI), where it was seen in the same area as previous sightings (Wilson et al. 2006; Bester and Reisinger 2010), it is impossible to say whether it is the same animal.

The sightings of Antarctic fur seals at Gough Island, the stronghold of A. tropicalis worldwide (Bester 1987; Bester and Ryan 2007), and the new sighting at Tristan, suggest that extralimital visits of $A$. gazella to the Tristan islands are now unexceptional. Moreover, the poor body condition and general lethargy of the individuals likely indicate that they are vagrants that made a fortuitous landfall to rest outside of their usual foraging range (Wilson et al. 2006; Bester and Reisinger 2010; this study). Vagrant A. gazella have been recorded at a number of localities around the Southern Ocean (Acevedo et al. 2011), but the Tristan sighting represents the northernmost oceanic island record for the species, although more northerly records $\left(33^{\circ} 08^{\prime} \mathrm{S}\right)$ of this species from mainland Brazil (Cherem et al. 2004) exist.

Such records suggest that $A$. gazella disperse from their breeding localities as populations recover after large-scale sealing of the $19^{\text {th }}$ and early $20^{\text {th }}$ century ceased (Wilson et al. 2006 and references therein). Hybridization between the two species at 
Antarctic fur seals at Tristan da Cunha islands

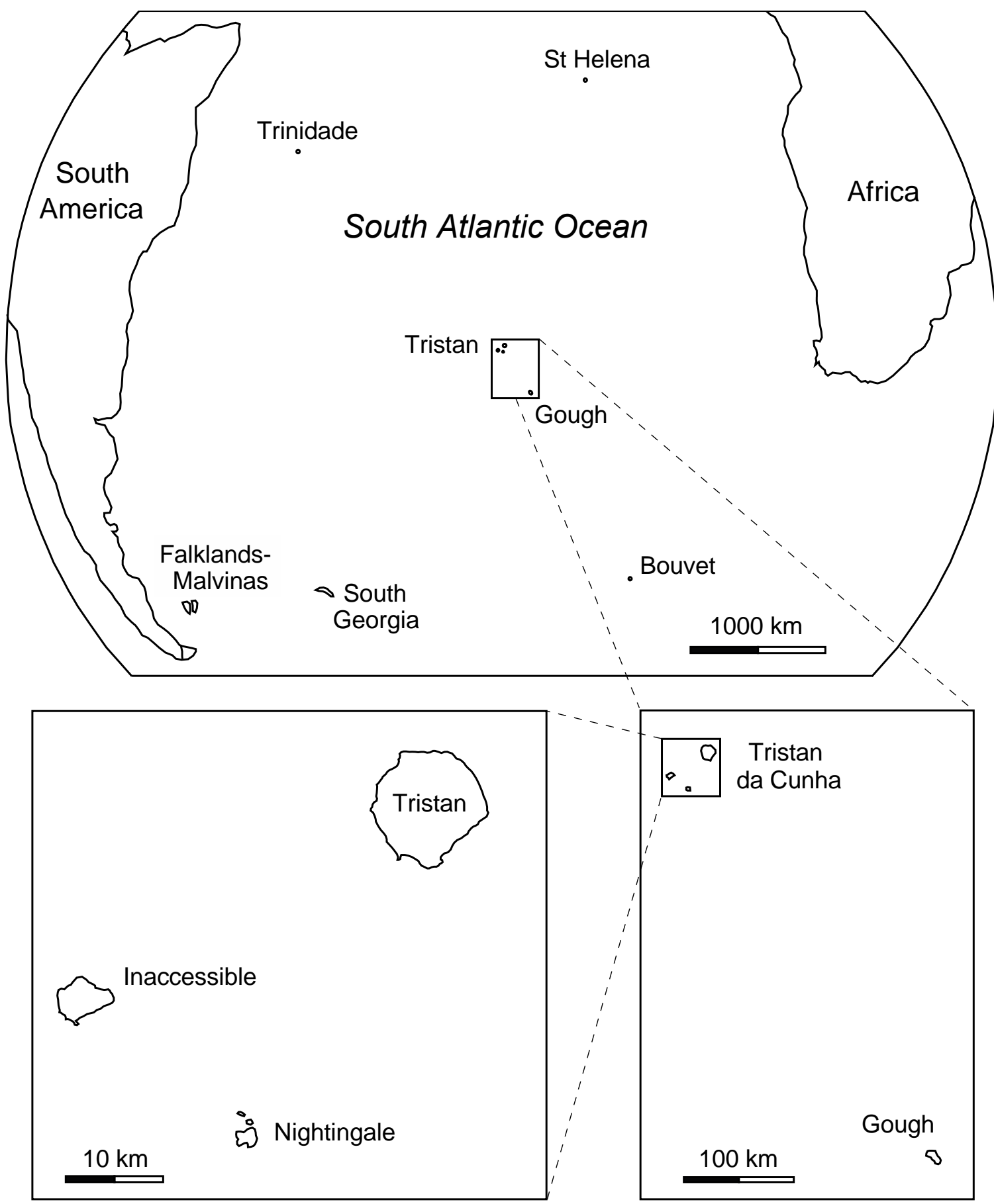

Fig. 1 Location of Tristan da Cunha and Gough Island, South Atlantic Ocean, where the vagrant Antarctic fur seals were sighted. 
Antarctic fur seals at Tristan da Cunha islands

(a)

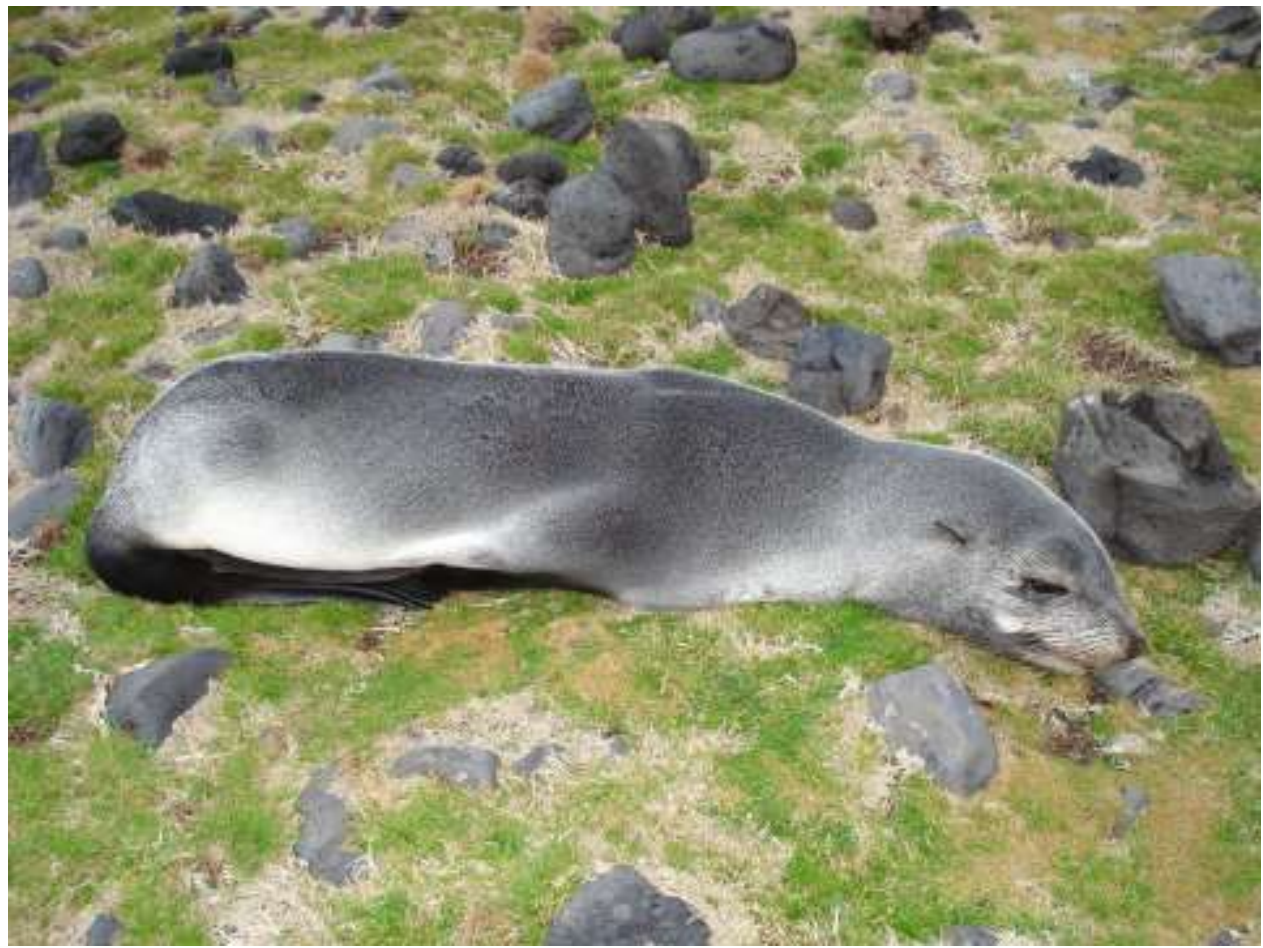

(b)

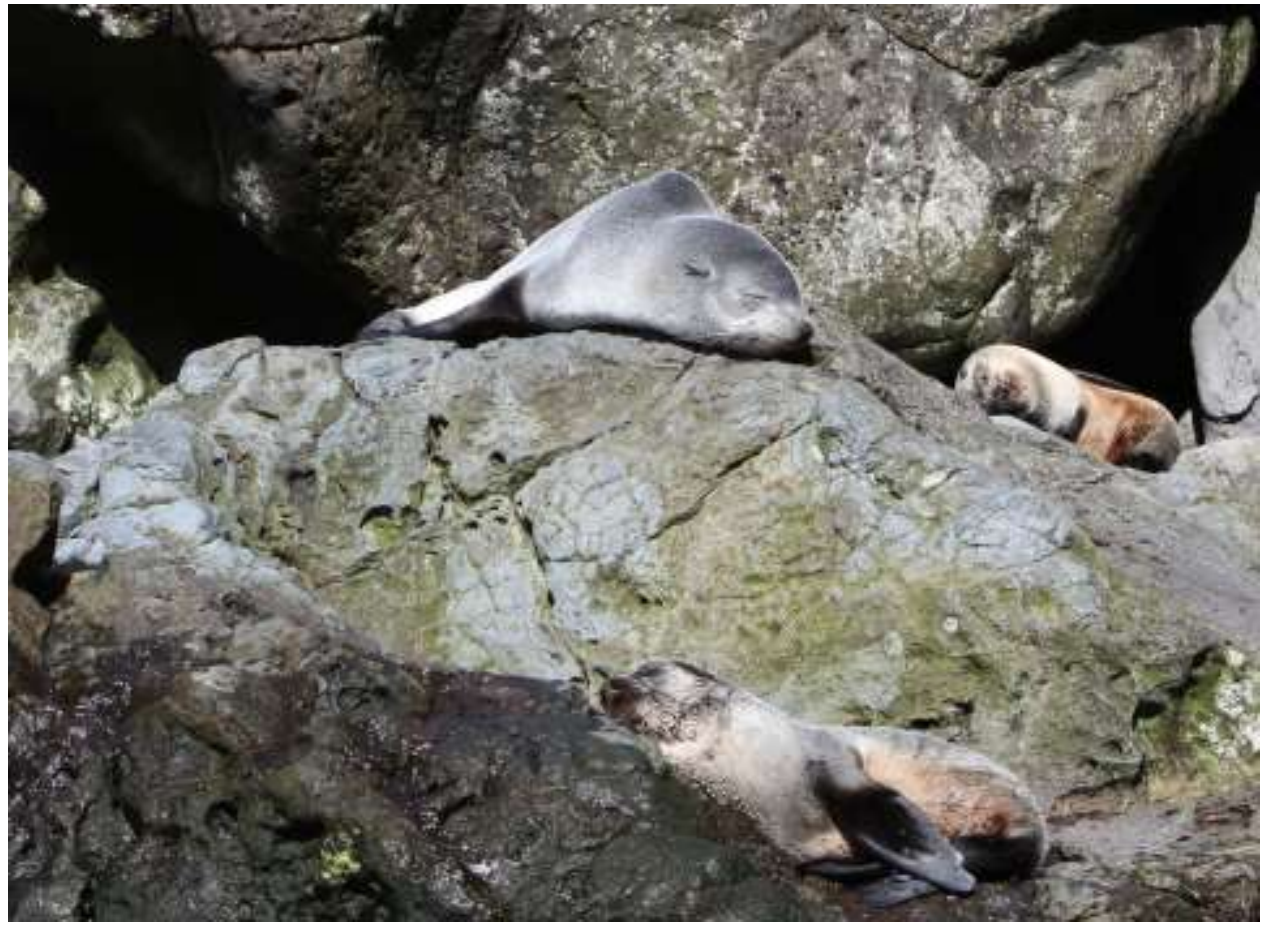

Fig. 2 Antarctic fur seals seen at Tristan da Cunha (a) and Gough Island (b) in September 2013 (photographs MN Bester and PG Ryan). 
Antarctic fur seals at Tristan da Cunha islands

Gough Island is unlikely (Wilson et al. 2006) and of limited impact due to the very large A. tropicalis population. However, the probable arrival of adult male A. gazella (Bester \& Reisinger 2010) at the small Tristan colony of A. tropicalis during the breeding season could conceivably result in hybridization akin to what has happened at, e.g., Marion Island (Condy 1978).

\section{Acknowledgements}

Logistical support at TdC and GI was provided by the South African Department of Environmental Affairs within the South African National Antarctic Programme. The Tristan da Cunha Conservation Department provided logistical and technical assistance at TdC. Research at both TdC and GI is conducted with the permission of the Administrator and Island Council of Tristan da Cunha.

\section{References}

Acevedo J, Matus R, Droguett D, Vila A, Aguayo-Lobo A, Torres D (2011) Vagrant Antarctic fur seals, Arctocephalus gazella, in southern Chile. Polar Biol 34:939943

Bester MN (1984) Status of the populations of the fur seals Arctocephalus tropicalis and Arctocephalus gazella north of the Antarctic Convergence. S Afr J Sci 80:27-28

Bester MN (1987) Subantarctic fur seal Arctocephalus tropicalis at Gough Island (Tristan da Cunha Group). In: Croxall JP, Gentry RL (eds) Status, biology and ecology of fur seals. NOAA Tech Rep NMFS 51:57-60

Bester MN, Reisinger RR (2010) Vagrant Antarctic fur seals at Gough Island in 2009. Polar Biol 33:709-711

Bester MN, Ryan PG (2007). Mammals. In: Ryan P (ed) Field guide to the animals and plants of Tristan da Cunha and Gough Island. Pisces Publications, Newbury. Pp 99-108

Cherem JJ, Simões-Lopes PC, Althoff S, Graipel ME (2004) Lista dos mamíferos do Estado de Santa Caterina, sul do Brasil. Mastozool Neotrop 11(2):151-184 
Antarctic fur seals at Tristan da Cunha islands

Condy PR (1978) Distribution, abundance and annual cycle of fur seals (Arctocephalus spp.) on the Prince Edward Islands. S Afr J Wildl Res 8:159-168

St. Clair Hill M, Ferguson JWH, Bester MN, Kerley GIH (2001) Preliminary comparison of calls of the hybridising fur seals, Arctocephalus tropicalis and A. gazella. Afr Zool 36:45-53

Wilson JW, Burle M-H, Bester MN (2006) Vagrant Antarctic pinnipeds at Gough Island. Polar Biol 29:905-908 